FARKAS TAMÁS - SLÍZ MARIANN szerk., Tulajdonnevek és szótárak. ELTE Magyar Nyelvtudományi és Finnugor Intézet - Magyar Nyelvtudományi Társaság, Budapest, 2020. 209-219. DOI: 10.26546/4892373.13

\title{
Magyar tulajdonnevek az ukrán névszótárakban
}

1. Bevezetés. Az ukrán névtudomány Ukrajna függetlenné válása (1991) óta jelentős fejlődésen ment keresztül. Az eredményes kutatás intézményi háttere már a szovjet időkben létrejött, a szervezett névtani kutatásokat ugyanis az Ukrán Tudományos Akadémia (UTA) Nyelvtudományi Intézetének (НАН України, Інститут української мови) névtani részlege koordinálja 1960 óta. ${ }^{1}$ Az akadémiai kutatómühely főbb projektjei közé tartozott korábban az ukrajnai víznevek összegyüjtése és szótárazása (SHU.), az oklevelekben előforduló tulajdonnevek etimológiai szótárának az elkészítése, valamint Ukrajna ősszláv névrendszerének a feltárása. Az ország méretei és névgazdagsága miatt nagyobb, országos méretü projektek, névgyüjtések lebonyolítására nem került sor. A hosszútávú tervek között szerepel ugyan Ukrajna helységneveinek történeti-etimológiai vizsgálata, eddig azonban sem a gyüjtö-, sem a feldolgozó munkáról nem jelentek meg írások.

Az UTA mellett az elmúlt évtizedekben több, névtudománnyal foglalkozó központ is létrejött, elsősorban az egyes felsőoktatási intézmények nyelvészeti tanszékein a nagyobb egyetemi városokban, például Lvivben, Rivnében, Ternopilban és Ivano-Frankivszkban. A kutatómunka eredményei a névtani jellegű tanulmányok, monográfiák, regionális helynévgyüjtések, névelméleti munkák, szótárak, egy-egy helynévtípus vizsgálatával foglalkozó monográfiák stb. nagy számában mutatkoznak meg. Az 1855-2000 közötti időszak névtani munkáit listázó, SzVJATOSZLAV VERBICS által szerkesztett, Ukrajinszka onomasztika. Bibliohraficsnij pokazscsik [Ukrán névtudomány. Bibliográfiai mutató] című ukrán névtani bibliográfia (VERBICS 2013) 4534 tételt tartalmaz, zömmel a 20. század második feléből. Emellett 2000 után számos, mérföldkőnek számító etimológiai szótár jelent meg, ami az ukrán onomasztika töretlen fejlődését mutatja.

Az ukrán névszótárak magyar eredetű anyagának vizsgálata kapcsán fontos megemlíteni, hogy az ukrán névtudomány (ellentétben például a szlovák és román nyelvészek vizsgálataival, vö. a jelen kötetben BAUKO JÁNOS [2020] által ismertetett szlovák és a BENÖ ATTILA [2020] által bemutatott román helynévszótárakkal) a kárpátaljai névkincscsel csak a terület Szovjetunióhoz való csatolása után kezdett foglalkozni. Szervezett, kiterjedt névgyüjtések ugyanakkor a mai napig nem történtek, a kutatók figyelme rendszerint egy-egy részkérdésre terjed ki. A kárpátaljai magyar névanyag kutatása még kevesebb figyelmet kap ukrán részről, aminek nyelvi és nyelven kívüli okai egyaránt vannak.

2. Helynévszótárak. Az ukrán névtudományban még nem készült a FNESz.-hez hasonló jellegü és terjedelmű helynév-etimológiai szótár. A kárpátaljai helységnevekről az első (és máig az egyetlen), ukrán nyelven született tudományos munka KIRILO HALASZ 1961-ben készült, Toponimija Zakarpatszkoji oblasztyi (nazvi naszelenih punktiv) [Kárpátontúl megye helynevei (településnevek)] című kandidátusi disszertációja. A dolgozat

${ }^{1}$ http://www1.nas.gov.ua/institutes/ium/Structure/Departments/Department6/Pages/ default.aspx (2020.05. 05.) 
kéziratban maradt, így szélesebb olvasóközönséghez nem jutott el, ugyanakkor az ukrán nyelvü szakirodalomban rendszeresen hivatkoznak rá. A 607 kárpátaljai településnév közül csak néhány tucatról mutatja ki a magyar eredetet, az évszázadokon keresztül használt magyar névalakokkal nem foglalkozik, etimológiáinak nagy része helytelen vagy félremagyarázott.

Egyes kárpátaljai helységnevek etimológiájával azonban két kiadványban is találkozhatunk. Az első, úttörő jelentőségű monográfia MIKOLA JANKO 1998-ban megjelent, Toponimicsnij szlovnik Ukrajini [Ukrajna helynévszótára] című szótára. Ez a kiadvány az Ukrán Oktatási Minisztérium tudománynépszerüsítő programja keretében készült, elsődleges célja a nyelv- és történettudomány eredményeinek szélesebb olvasóközönséghez való eljuttatása. A szótár Ukrajna legfontosabb helységeinek, járási központjainak, ún. városi típusú településeinek, ismertebb falvainak, valamint történelmi, kulturális stb. szempontból fontos helyeinek a nevét tárgyalja etimológiai szempontból. Az elsődleges célközönség a diákok, középiskolások, egyetemisták korosztálya, de például tanárok a helytörténeti, nyelvészeti oktatásban segédkönyvként is használhatják. Ez a cél teljes mértékben meghatározza a szótár szerkezetét, illetve tartalmát. A szócikkek rövidek, kevés információt tartalmaznak, a részletes etimológiai vizsgálatra és bizonyításra a szerző nem fordít megfelelö figyelmet. JANKO eltekint a nevek történelmi adatainak a közlésétől, a hivatalos nevekből kiindulva etimologizál, az esetleges korábbi, történelmi névváltozatokkal - ezáltal az eredeti etimológiákkal - ritkán foglalkozik. Ezt kiemelten fontos figyelembe venni a szótár kárpátaljai névkorpusza kapcsán, ugyanis a hivatalos helységnevek rendszerébe 1946-ban jelentős beavatkozás történt. A szótár mintegy 50 kárpátaljai nevet tartalmaz. A helységnevek közül Beregszász, Nagyberezna, Nagybocskó, Tiszaújlak, Nagyszölös, Volóc, Bátyú, Dombó, Ilosva, Gyertyánliget, Királyháza, Ökörmezö, Munkács, Alsóverecke, Perecseny, Rahó, Szolyva, Szerednye, Aknaszlatina, Taracköz, Ungvár, Királymezö, Huszt, Szentmiklós, Körösmezö hivatalos ukrán nevét vizsgálja.

1. ábra: Beregszász nevének névcikke (JANKO 1998)

\begin{abstract}
Бе́регове - м., рц. Закарпатської обл. Розташоване в долині p. Тиса (бас. Дунаю). Виникло в XI ст., входило до складу Київської Русі. 3 кінця XI ст. під владою Угорщини. Назва від слов. берег «ділянка землі біля води, гора» та суф. -ов(е). Звідси ж назва Берегівські горби - підвищення, розташовані на пд. 3х. Закарпатської, низовини, сх. від м. Берегового.
\end{abstract}

A víznevek köre szinte kizárólag a nagyobb folyókat öleli fel (Fehér-Tisza, Borzsova, Latorca, Nagy-ág, Szinevér, Talabor, Tisza, Túr, Ung, Fekete-Tisza), de egy-két kisebb, kevésbé ismert patak neve is bekerült a szótárba (pl. Bogdán, Bronyka, Sipot). A Kárpátaljára leginkább jellemző hegynevek közül csak a Beszkidek, Bliznica, Gorgánok, Priszlop és a Szinyák nevekről, illetve a legfontosabb hágók nevéröl ír (pl. Vereckeihágó, Volóci-hágó, Ruszkij Puty, Uzsoki-hágó, Tatár-hágó). A szótár a szláv eredetű nevek többé-kevésbé megbízható etimológiáját adja, a magyar vagy magyar vonatkozású nevek esetében azonban hajlamos a tények elferdítésére vagy mellözésére, gyakran esik a népetimológia csapdájába.

Beregszász szükszavú szócikkében például olyan, forrásokkal, adatokkal alá nem támasztott információk olvashatók, miszerint a város a 11. században jött létre, s a Kijevi 
Ruszhoz tartozott, de a század végétől Magyarország uralma alá került. A helységnevet a szl. bereg 'víz melletti földdarab, part, hegy' főnév -ов(e) melléknévképzős származékának tartja, így annak jelentése tkp. 'part menti, hegy melletti'.

A Munkács név magyarázatánál a városról szintén azt írja, hogy bár alapításának ideje bizonytalan, egyértelmü, hogy a 9-10. században a Kijevi Rusz része volt. A település konkrét adatainak hiányában állítja a szerző az ősi szláv államhoz való tartozását. Az 1946-tól hivatalos ukrán Мукачів névalakot magyarázza, a történelmi Munkács névformát megemlíti ugyan, de az etimológia szempontjából nem tartja relevánsnak.

2. ábra: Munkács nevének névcikke (JANKO 1998)

Мука́чеве (Мука́чів) - м., рц. Закарпатської обл. Розташоване на обох бер. р. Латориця (бас. Дунаю), на стику відгорів Вулканічних Карпат і Закарпатської низовини. Час заснування невідомий. Гадають, шо воно виникло в IX-X ст. М. входило до складу Київської Русі. В письмових джерелах уперше згадується в 1196. Походження назви не встановлено. Існує кілька легенд $\mathrm{i}$ народних переказів про її утворення. У хронікальних записах і в науковій літературі зустрічаємо варіанти Мункач, Мункачів, що вказує на можливість походження назви міста від угор. мунка «праця, труд» (пор. 3 укр. Трудовач, Трудниия, Трудолюбівка). Проте найбілыш вірогідне припущення походження назви міста від імені Мукач, утворена присв. суф. -ів. У наш час не виправдано змінено ім. форму назви на прикм.

A szerző által vallott sajátos történelemfelfogás a Kárpátalja névről írt szócikkében is tetten érhető: Kárpátontúli Ukrajna vagy Kárpátontúl ugyanis szerinte történelmi régió, amihez hozzátartozott a mai Kárpátontúli megye, s azon földek részének tekinti, ahol a keleti szlávság létrejött.

3. ábra: Kárpátalja nevének névcikke (JANKO 1998)

Закарпа́тська Украй́на, Закарпаття (Підкарпатська Русь) - історична територія, до складу якої входила суч. Закарпатська обл. Частина земель, на яких створювалося східне слов'янство [УРЕ II, 4, 71]. Назва від розташування за Карпатами. Утворена від основи Карпат- преф. за- і суф. -ськ(а).

A szótárra jellemző az a hivatalos ukrán történelemszemlélet, általánosan elfogadott és tanított dogma, mely szerint a mai Kárpátalja területén a honfoglalást megelőzően keleti szlávok éltek, akiknek - az egyébként nemzetiségként el nem ismert - ruszinok az egyenes ági leszármazottai. A magyarok bejövetele előtt egy feltételezett szláv államot vizionálnak, ami a Kijevi Ruszhoz tartozott, így a területnek a Szovjetunióhoz, majd Ukrajnához való csatolását újraegyesülésként (возз'єднання) értelmezik és tanítják. JANKO szótára ennek szellemében íródott, hiteles adatokkal nem dolgozik, ezért tudományos kutatásra kevésbé alkalmas, a bevezetőben kitüzött népszerüsítő és hazafias gondolkodásra nevelő célt azonban minden bizonnyal megvalósítja. Hasonló szemlélet 
más határon túli régiókban is visszaköszön: a szlovák STANISLAV a kárpátaljai helyneveket szintén a szlávból magyarázza (vö. STANISLAV 1948; a felvidéki nevekhez 1. BAUKO 2020), a román DRĂGANU pedig mindenhol román neveket vél felfedezni (vö. DRĂGANU 1933; az erdélyi névanyaghoz 1. még BENÖ 2020).

A laikus közönség számára készülö, névtant, nyelvészetet népszerüsítő munkák mellett idővel felmerült egy pontosabb, tudományos alapokon nyugvó helynévszótár létrehozásának igénye. A két szempontot kívánja ötvözni, valamint a névtan legfrissebb eredményeit a nagyközönség elé tárni VASZILIJ LUCSIK Etimolohicsnij szlovnik toponimiv Ukrajini [Ukrajna helyneveinek etimológiai szótára] című, 2014-ben megjelent etimológiai szótára. ${ }^{2}$ A szerző az UTA Nyelvtudományi Intézetének munkatársa, évtizedek óta foglalkozik helynévkutatással, elsősorban víznevekkel és földrajzi köznevekkel. A szótár közvetlen elözménye a JANKO-féle kiadvány, a két szótár között mind a szócikkek, mind azok tartalma között jelentős átfedés tapasztalható. Ugyanakkor LUCSIK a hibákat figyelembe véve egy részletesebb és pontosabb szótár elkészítését, a hiányosságok pótlását tüzte ki célul. A kötet 2600 szócikkben mintegy 3700 földrajzi név etimológiáját tárgyalja. Vizsgálata a helynevek minden típusára és Ukrajna teljes területére kiterjed. A szótár elsődleges bázisát a makrotoponimák (víznevek, domborzati és településnevek) alkotják, de foglalkozik például természetvédelmi területek, erdők, dülők elnevezéseivel is. A névkorpuszban mintegy másfélszáz kárpátaljai toponima magyarázata található meg, zömmel önálló szócikkben. A teljesség igénye nélkül a következő nevek magyarázatai szerepelnek a kötetben:

- Helységnevek: Ungvár, Munkács, Csap, Beregszász, Huszt, Nagyszölös, Ilosva, Perecseny, Rahó, Szolyva, Técső, Bátyú, Bustyaháza, Nagyberezna, Nagybocskó, Tiszaújlak, Visk, Volóc, Dombó, Zsdenyova, Kölcsény, Gyertyánliget, Királyháza, Ökörmezö, Szerednye, Aknaszlatina, Taracköz, Királymezö, Szentmiklós, Körösmezö.

- Víznevek: Tisza és mellékágai, Apsica, Apsinec-tó, Bajlova, Bruszturjanka, Horodilovai vízesés, Ilosva, Kerepec, Krivulya, Mokrjanka, Pinye, Pomejnica, Repinka, Szalva, Vicsa stb.

- Hegy- és hágónevek: Berlyaszka, Beszkidek, Gorgánok, Bliznica, Bouvan, Borzsahavas, Brebenyeszkul, Hoverla, Gutin-Tomnatek, Kobila, Popagya, Pop Iván, Priszlop, Rebro, Ruszka, Szvidovec, Jabloncai-hágó, Vereckei-hágó, Uzsoki-hágó, Volóci-hágó, Toronyai-hágó stb.

A szócikkek felépítése már a filológiai igényü etimológiai szótárak szokásos eljárását követi. A hivatalos, ukrán nevek mellett sajnos a népnyelvi adatokat, névvariációkat nem közli a kiadvány, de a lokalizálás után a nevek történeti adatait közreadja. Ez a szerző hangsúlyozott újítása, ugyanis a korábbi etimológiai szótár fő hiányossága éppen ennek a mellőzése volt. Sajnos LUCSIK sem tudja teljes mértékben teljesíteni a célkitüzését. Az eltérő történelmi múlttal rendelkező ukrán területek múltjának dokumentumai, oklevelei főként külföldi (lengyel, magyar, osztrák, román, orosz stb.) levéltárakban vagy nyomtatásban megjelent adattárakban találhatók. Megismerésük és feldolgozásuk ukrán részről a mai napig nem történt meg. Ezzel magyarázható, hogy történeti adat helyett csak egy évszámot vagy még azt sem közöl a szerző. A kárpátaljai településnevek adatait rendszerint HALASZ korábban hivatkozott munkájából (1961), közvetett és kevésbé megbízható forrásból meríti.

\footnotetext{
${ }^{2}$ Részletes ismertetését 1. SEBESTYÉN 2016.
} 
4. ábra: Beregszász nevének névcikke (LUCSIK 2014)

Бе́регове - місто, Закарпат. обл. [АТП, 156]; засн. в XI ст. [ГЕУ 1, 83], сакс. $Z a z=$ угор. Szàsz (1141), Bereg (1214), Lampertszàsz, Lamprechtszàsz, Lam. perthàz, Luprechtszasz (XIII ст.), Beregszàsz [Галас, 58], Бépezoвo (1981) [CЭС, 132]. Суч. ойконім виник унаслідок субстантивації та онімізадії відн. прикм. береговйй фрозміщений, розтапований на прибережних ділянках [СУМ 1, 158] у формі сер. роду, яка узгоджуе ойконім з номенкл. іменем село, поселення, місто; пор. назву нп Берегове в Криму і в різних обл. Укряїви [ATI, 581]. В основі твірного прикм. ГТ бе́рег (днв. Бе́pez), який під пд.слов. та герм. впливом на Закарпатті міг виражати також актуальне знячення "гора" й закріпитися в істор. назвах пос. Bereg і Beregszàsz. Найдавніша форма $\mathrm{Zaz}$, якій відповідає угор. Szàsz, постала семант. способом від етноніма $z a z, s z d \dot{s} z$ "саксонець", що відбився в прізв. закарп. україндів [Чучка, 503]. Композитні сакс. та угор. назви з цим компонентом включають фонет. варіанти герм. антроповіма Ламперт [Галас, 58]. Перевесення наголосу на перший склад ойконіма Бе́регове 3 останнього у твірному береговйй «стос. до бе́реz" зумовлене впливом угор. мови; пор. оронім Бе́регівське горбогір'я, що називає масив плосковершинних вулкав. горбів і розчлевованих силових поверховь побл. м. Береговоzo [ГЕУ 1, 82], суміж. с. Nagy Bereg, укр. Вереги [Галас, 58] і ще 13 ойконімів Берегове в різних регіонах України [ATI, 581].

A teljes magyar vonatkozású névanyag bemutatásától természetesen eltekintek, de érdemes összehasonlítani JANKO és LUCSIK etimológiai szótárának egy-két szócikkét. Beregszász-szal nagyobb terjedelemben foglalkozik, közli a település korábbi névalakjait is (Szász, Lampertszász, Beregszász). Elsődlegesen a mai hivatalos helységnevet (Берегове) etimologizálja, ami szerinte az ukrán береговий 'part melletti helyen telepített (falu, város)' melléknév származéka. Úgy véli azonban, hogy a melléknév alapjául szolgáló берег fönév másodlagos 'hegy' jelentése figyelhető meg a helység régi Bereg és Beregszász nevében, mivel a város hegy lábánál települt. A legkorábbi Szász formát - helyesen - a szász népnévből eredezteti, míg a Lampert nevet személynévi eredetünek tekinti. A magyar településnévhez füzött magyarázatai tehát megfelelnek a valóságnak (vö. FNESz. Beregszász, SEBESTYÉN 2010: 25). A helységnév szláv eredeztetése azonban téves. Példaként megemlíti ugyan a megyének is nevet adó Nagybereg helységet, azzal azonban nincs tisztában, hogy a Bereg- előtag Beregszász nevében a megyére utal, s nem a város melletti hegyre.

Hasonló részletességgel tárgyalja a szerző Munkács nevét. A mai Мукачеве helységnévből indul ki, ami szerinte „ukrán környezetben” keletkezett, s a Mukacs személynév birtoklást kifejező -ове/-еве képzős származéka. Kitér a személynév magyarázatára, amelynek szerinte а мукати 'dörmög, dünnyög' ige az alapja. Úgy véli, hogy az -aч képző különböző víznevek hatására kerülhetett a helységnévbe. A magyar Munkács névalak szerinte másodlagos, létrejöttében szerepet játszhatott az ősszláv munka fönévvel való összecsengése, amit már Anonymus is említ (An. 12). (A név tudományos névfejtését 1. FNESz. Munkács, SEBESTYÉN 2010: 99.) 
5. ábra: Munkács nevének névcikke (LUCSIK 2014)

\begin{abstract}
Мука́qеве - місто, Закарпат. обл. [АТП, 16i] ; відоме з IX ст. [ГЕУ 2, 393], за ін. джерелами - згадується 1196 р. і має варіанти Мука́чів, Мункач, Мункачів [Янко, 237]; Munkács [Галас 1957-a, 204], як відоме з XII ст., Мука́чево (1981) [СЭС, 854]. Суч. ойконім виник в укр. середовищі як посесив на -ове / -еве, варіант -ев / -ів, від антропоніма Мукач з основою дієсл. мукати *мугикати», який відомий у пол. мові як $M u k$-acz 31430 p. [Rymut 2, 124]; пор. серб., хорв. апелятив мукац *жаба-джерелянка i похідний від нъото топонім Mukačije [Галас 1957-a, 204 ] із суф. -ije в посес. функціі. Завдяки суф. - $а ц$ у структурі твірного слова ойконім міг функщіонувати без додаткових афіксів подібно до гідроніків Головач, Рөач, Лукач, Тлумач, Лехач [Трубачев, 225], що відбиває угор. Munkács, у якому звукосп. -иn- постало під впливом запозиченого д.слов. тunka *мука" (< псл. *mpka), на що вказуе у зв'язку з назвою Мукачеве ще Анонім; пор. у Потиссі угор. топонім Mukacs без вос. - un- в основі [Галас 1957-а, 204] i закарп. прізв. Му́нка, Мункач, Мункачі, Мункаш, Мункоєи о таким дифтонгом в угор. джерелах [Чучка, 402].
\end{abstract}

A szerző javára kell írnunk ugyanakkor, hogy több esetben javítja JANKO hibás etimológiáit. A Munkács melletti Szentmiklós ukrán nevéről (Чинadiєвe) adott JANKO-féle népetimológiás magyarázat helyett mind a magyar, mind az ukrán név pontos jelentését közli: az előbbi védőszent nevéből, az utóbbi képzős személynévből ered. Helytálló etimológiái mellett számos esetben tévesen elemzi a helységneveket, amit kevésbé róhatunk fel a szerző hibájaként, ugyanis magyarázatainál elsősorban HALASz (1961) kéziratos munkájára támaszkodik. A Bátyú helységnévnél például az 1995-ig érvényben lévő hivatalos ukrán nevet tárgyalja (Вузлове), illetve az újabb, ukránosított Батеве névalakra is kitér. A hagyományos, történelmi Bátyú névröl azonban szót sem ejt, így a helységnek egy szláv eredetü, képzéssel létrejött nevet kreál, szemben a puszta személynévi eredetü magyar névvel (vö. FNESz. Bátyú, SEBESTYÉN 2010: 22). Hasonló az eljárása a szintén magyar, puszta személynévi Técső névnél is (vö. FNESz. Técsö, SEBESTYÉN 2012: 139), aminek a hivatalos Тячів alakját a Тяч személynév birtoklást kifejező -iв képzős formájának tartja, holott az a magyar név ukrán kiejtéshez igazított adaptációja.

Bár LUCSIK szótára a JANKO-féle kötettel összevetve tudományos szempontból pontosabb, a modern névtudományi elveknek kevésbé felelnek meg a szótárak névcikkei. A szerzők nem vagy csak szórványosan közlik a denotátumok adatait, valamint a névfejtések a szláv eredet ideológiáitól sem mentesek, sőt többször megfigyelhető az adatok értelmezésében az anakronizmus.

3. Személynévszótárak. Az általános helynévszótárakkal ellentétben ukrán nyelven számos személynévszótár jelent meg, bár ezek mind módszerükben, mind a vizsgált névkorpusz tekintetében jelentős eltéréseket mutatnak. Kárpátaljai, illetve magyar vonatkozású névanyag általában ritkán szerepel ezekben a kiadványokban. Az ukrán személynévkutatás legfontosabb szótára azonban teljes mértékben a kárpátaljai személynévkincsre támaszkodik. 2005-ben jelent meg PAVLO CSUCSKA Prizviscsa zakarpatszkih ukrajinciv. Isztoriko-etimolohicsnij szlovnik [A kárpátaljai ukránok családnevei. Történeti-etimológiai szótár] címü, a kárpátaljai ukránok családneveit bemutató történeti-etimológiai szótára. ${ }^{3}$ A szerző az 1970-es évek óta foglalkozott a kárpátaljai ukrán családnevekkel, a 702 oldalas szótár évtizedes gyüjtő- és kutatómunkájának az eredménye. A kötetben jelentős a magyar eredetü nevek aránya, ami azzal magyarázható, hogy ukránnak tekinti a közép-

\footnotetext{
${ }^{3}$ Részletes ismertetését 1. SEBESTYÉN 2009.
} 
korban még a nyelvhatáron fekvő, magyar többségű vagy vegyes lakosságú, de mára elukránosodott települések lakosságát, s az ő neveiket is felveszi a szótárba. CSUCSKA tudományos igénnyel megírt szótára kiemelkedő jelentőséggel bír mind az ukrán, mind a magyar névtudomány számára. A magyar eredetű névkorpusz részletes bemutatására itt nem térek ki, csak két névtípus segítségével bemutatom a szerzőnek a szótárban elöforduló, már-már típushibának tekinthető és vitatható eljárását.

A szótárban elemzett, egyértelműen magyar nevek esetében a szerző rendszerint elsődlegesen nem a magyar, hanem az ukrán nyelvből igyekszik magyarázatot találni a néveredetre. Ez a törekvése a legszembetünőbb módon a foglalkozásnévi eredetű családnevek körében figyelhetö meg. A nyelvi érintkezés nyomán a helyi ukrán nyelvjárásokban ugyanis jövevényszóként számos magyar foglalkozásnév él (vö. CSOPEI 1883). CSUCSKA úgy véli, hogy ezekből a foglalkozásnevekből már az ukrán névadók hoztak létre családneveket, holott családnévvé válásuk valószínüleg még a magyar névadásban történt meg. Ezt a példaként hozott korai történelmi adatok is alátámasztják, amik jellemzően a korábban magyar (vagy részben magyar) településekröl származnak. A Lakatos és Kondás családnevekre példaként Ugocsából említ 1565-ös adatokat (Szászfaluból és Fancsikáról; a két faluban még ma is élnek magyarok), holott ekkor a ruszinok körében - állítása szerint - még nem voltak családnevek. Mindkét esetben magyar jövevényszóból magyarázza az etimológiát. A foglalkozásnévi eredetü családnevek körében szinte kivétel nélkül ezt az irányt követi, mesterségesen „szlávosítva” őket, pl. Сабов (Szabó), Бийреш (Béres), Варта (Varga), Кочіи (Kocsis), Сокач (Szakács).

Ugyancsak több esetben vitathatók a helynévi eredetü családnevekhez füzött magyarázatai. A mind a belső, mind a külső migráció által nagy mértékben érintett területen jelentős a helynevekből létrejött nevek aránya a magyar és a helyi ukrán névadásban. A magyar - $i$ képző ukrán -ський, -цький megfelelöjével számos családnév keletkezett, CSUCSKA azonban az ukrán eredetủek közé sorol olyan családneveket is, amelyek egyértelműen magyar névalkotással jöttek létre. A foglalkozásra utaló neveknél alkalmazott szlávosítás, az ukrán etimológia kényszeredett erőltetésének hatása alól itt sem tudja függetleníteni magát. Ennek példáit hosszasan sorolhatnám, illusztrációként csak egykét jellegzetes nevet emelek ki.

6. ábra: A Lipcse (Lipcsej) családnév névcikke (CSUCSKA 2005)

\footnotetext{
Липче́ї [Личчи́ü], -ея́-Xc, Тч, lp, Мж, Уж. 1542, 1550, 1600: вл. Jo. Lypchey - Липча (Bélay 171); 1550: шл. Sim. Lipchei-Руське Поле (Bćlay 211); 1600: кр.Gc. Lipczei-Буштино (Bélay 132); 1600: землевласник Lipcsei Ferena - Голятнн (Bélay 147); 1726: Лunчей Прода" - Сокирниця (Гаджега-М 75). 1. Укр. патр. 3 суф. -ей від антр. Лйпча. 2. Угор. утворення 3 формантом -i від укр. ойк. Липча (по-угор. - Lipcse, а по-рум. - Lipsa). Останне відбнлося й на деякнх офіційннх запнсах п-щ. Пор. рум. п-ща Lipsa, Lipsci (Iordan 280).
}

A szótárban szerepel a Липчей (Lipcsej) családnév, amely a magyar Lipcsei név ukrán kiejtéshez igazított alakja. A helységnévből keletkezett magyar családnevek ukrán 
adaptációiban gyakran találkozunk a szóvégi magyar -ai/-ei hangkapcsolatok -aŭ/-eŭ megfelelőivel. CSUCSKA azonban a Липчей nevet elsődlegesen személynévi eredetűnek tartja: úgy véli, hogy az az ukrán Липчa személynév -eŭ képzős alakja. Illeszkedéssel viszont a Липчаŭ forma lenne a szabályos. Érezvén az etimológia bizonytalanságát és erőltetettségét, másodlagos magyarázatként megemlíti, hogy a név származhat a máramarosi Lipcse helységnévböl is, magyar - $i$ képzővel (legkorábbi adatát is erröl a településről hozza!). A Бедеŭ (Bedei) családnevet Bedőházáról említi, mely település neve évszázadokon keresztül Bedő alakban volt használatos. A név lehetséges etimológiájaként elsőként ősszláv, majd magyar vagy horvát személynevet hoz, végül harmadik eshetőségként a Bedö helységnév - $i$ képzős származékát is megemlíti. Ezt az eljárást követi még а Бачкай (Bacskai), Добай (Dobai), Добрай (Dobrai), Довгай (Dovhai, de minden történelmi adata Dolhai), Долинай (Dolinai), Левай (Lévai), Мортітай (Margitai), Ревай (Révai), Редей (Rédei), Сіксай (Szikszai) stb. neveknél is. A helynévi eredetü családnevek körében elöforduló tévedéseire részben magyarázat lehet a magyar szakirodalom, illetve a forrásmunkák, történeti helységnévtárak, a történelmi helynévanyag hiányos ismerete.

7. ábra: A Sztritei (Sztritej) családnév névcikke (CSUCSKA 2005)

\section{Cтрітеи †. 1523: Zitrithei Pal - Зняцьово (LehBcr 309). $\triangleleft$ Уrop. п-щс з суф. -і від якогось ойк, на зразок Cmpime.}

Jól illusztrálja ezt a kihaltnak feltüntetett Cmpimeŭ (Sztritei) családnév, melynél szlávosítja az egyetlen, Ignéc faluból származó 1523-as Ztrithei adatot, mert a település ma ukrán lakosságú, holott a középkorban még magyar volt. A nevet egy „valamilyen” Sztrite helységnévből a magyarban képzett alaknak tartja, amire nincsenek adatai. A település azonban nem ismeretlen a kárpátaljai magyar kutatók számára, hiszen az a Csucska szülöfalujától, az ungi Baranyától 10 km-re (!) fekvő mai Szürte (vö. SEBESTYÉN-ÚR 2014: 113-4).

8. ábra: Az Újbári (Ujbarij) családnév névcikke (CSUCSKA 2005)

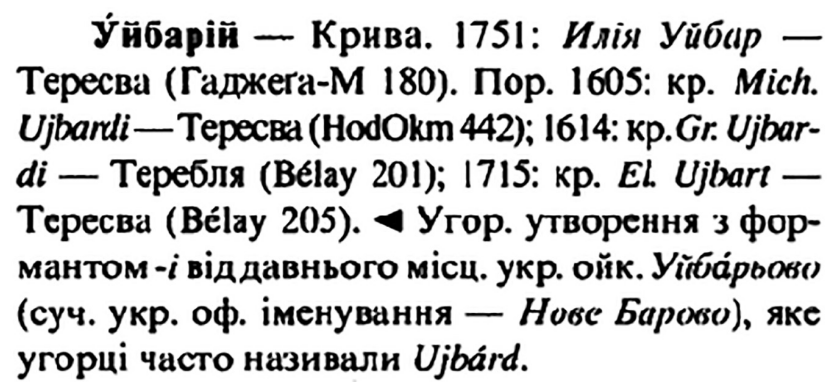

Végezetül még egy jellemző példa a történeti adatok kezelésével és értelmezésével kapcsolatban. Az Уüбаріü (Ujbári) családnévhez hozott történelmi példái: Ujbar, Ujbardi és Ujbart. Más neveknél is gyakran elöfordul, hogy a történelmi formák nem egyeznek meg a vizsgált családnévvel. A nevet ugyan magyar eredetünek tartja, de az szerinte a „régi ukrán Ujbarjovo" helységnév - $i$ képzős alakja, mely helységet a magyarok „gyakran Ujbárd-nak nevezték”. 
CSUCSKA szótára mellett érdemes megemlíteni még egy ukrán nyelvü, de nem Ukrajnában készült kiadványt. 2003-ban jelent meg Eperjesen MiKOLA DUJCSAK Antroponimija Pjasivcsini [Eperjes vidékének személynevei] címü szótára, amely a felvidéki Eperjes környékén élő ukránok családneveit tartalmazza. A gyüjtés 270 szlovákiai, zömmel ukrán nemzetiségü falura terjedt ki, s a településekröl 4278 nevet közöl. Célja a mai családnévanyag összegyüjtése és szótárazása volt. A szerző a személynevek nyelvészeti (etimológiai, szemantikai, alaki) szempontú vizsgálatát tüzi ki elsődleges feladatként, s bár az etimológiai elemzés kiemelt szempontként szerepel a bevezetőben, a nevek eredetének magyarázatára a szerző nem tér ki minden szócikkben.

Az idegen eredetü, magyar, német, román, szlovák családnevek a teljes névállomány mintegy 20\%-át teszik ki. Körülbelül két tucat név esetében jelzi a szerző a közvetlen magyar eredetet: Адзіма (Hagyma?), Андраш (András), Андраші (Andrási), Apвай (Árvai), Барна (Barna), Варга (Varga), Галас (Halász), Гал (Gál), Йуzac (Juhász), Лаката (Lakat), Секела (Székely), Терек (Török), Чікош (Csikós) stb. Ennél nagyobb számban szerepelnek a szótárban ugyanakkor olyan családnevek, amelyek esetében DUJCSAK nem utal a név eredetére, de egyértelmüen magyar származékról van szó: Байус (Bajusz), Бакош (Bakos), Балог (Balog), Бан'ас (Bányász), Барат (Barát), Бочкай (Bocskai), Будай (Budai), Batami (Vágási), Веспремі (Veszprémi), Вірак (Virág), Вісокай (Viszokai), Гетедуш (Hegedüs), Габор (Gábor), Гонос (Gonosz), Добош (Dobos), Ештван (Estvan), Камараш (Kamarás), Корпонай (Kогропаi), Кормош (Kormos), Кочіш (Kocsis), Легін' (Leginy), Мінд’ap (Mingyár), Héмem (Német), H’ертеш (Nyerges), Петровай (Petrovai), Пушкаш (Puskás), Ракоціi (Rákóci), Сабо (Szabó), Фаркаш (Farkas), Чонтош (Csontos) stb.

9. ábra: A Bányász családnév névcikke (DUJCSAK 2003)

'БАН'АС, -А Вд-1/6, Ки-2/9, Мп-5/12. До Бан'аса - Андрій Родак [його отец пристал До Бан'аса] ВП, Бан'аска - Іл’а Бружкына [3 Кожуховец за слоб.] Вк. Banyász, Bañas ПКК Мп. Оф. Ban̆as.

10. ábra: A Kocsis családnév névcikke (DUJCSAK 2003)

КОЧІШ, -А Мц-1/4 [з Гіралтовец], Ок-1/3 [3 Керештвсіัа], Шн-4/13 [гурал'i]. Oф. Kočiš.

Végül, bár nem személynévszótár, de mégsem hagyható ki a felsorolásból CSOPEI LÁSZLÓ ruszin-magyar szótára (CSOPEI 1883). A mü jelentős keresztnévanyagot tartalmaz, ezért egyfajta 19. századi ruszin-magyar névjegyzékként is használható; pl. Абрунъ Ábris, Ábrahám, Акакий Ákos, Алексий Elek, Aндрей András, Andor, Endre, Антоний Antal, Tóni, Apuй Áron, Викторъ Gyözö, Георгий György, Gyuri, Gyurka, Дмитрий Demeter, Döте, Евгений Ödön, Иванъ János, Jancsi, Iván, Илий $\sim$ Illés, Микула Miklós, Петро $\sim$ Péter, Федоръ $\sim$ Tódor stb.; Варвара Borbála, Biri, Гафа Agápia, Ева Éva, Елизавета Erzsébet, Örzsi, Ирина Irén, Irénke, Катерина Katalin, Katica, Kati, Магдалина Magdolna, Одарка Dorottya, Олена Ilona stb. 
CSOPEI nemcsak a személynevek ,hivatalos” formáit közli, hanem szép számmal adatolja a beregi ruszin beceneveket is: Васьо $\sim$ Vaszily kicsinyítve, Грицько $\sim$ Gerö, Gergely, Данко Dániel, Дзуря György, Gyuri, Илько Illés, Леųа Sándor, Луц̧ьо Lukács, Мrъшка Miska, Палий Pál, Pali, Тоний Antal, Tóni, Яиько Jakab stb.; Анияя Anna, Anica, Anikó, Галька Ilka, Ilona, Ilonka, Eржа Erzsi, Örzsi, Örzsébet, Маруня Mariska, Marcsa, Mária, Настя Neszti, Eszti, Oришко Irén stb.

4. Összegzés. Rövid összefoglalásként elmondható, hogy a mai Kárpátalja területén az évszázados ukrán (ruszin) és magyar együttélés nyomán sajátos hely- és személynévkincs jött létre, ami mindkét nemzet névtudósai számára lehetőséget nyújt a kutatásra. A vidék peremterület jellege miatt azonban sajnos általában kiesik a kutatók látóköréből. A röviden bemutatott ukrán hely- és személynévszótárak némelyike a tudományos megközelítés mellett sajnos egyoldalú ideológiai és politikai célokat is szolgál, ami gátolja az objektív következtetések levonását.

\section{Felhasznált források}

CSOPЕI = ЧОПЕЙ, ЛАСЛОВЪ 1883. Русько мадярский словарь. Будапешть.

CSUCSKA 2005. = ЧучКА, ПАВЛО 2005. Прізвища закарпатських украйнців. Історикоетимологічний словник. Видавництво „Світ”, Львів.

DUJCSAK 2003. = ДуйЧАК, МиКОЛА 2003. Антропонімія Пряшівщини. К. п., Пряшів.

HALASZ 1961. = ГАЛАС, КИРИЛО 1961. Топоніміка Закарпатської області (назви населених пунктів). Ужгород. Kézirat.

ЈаNко 1998. = Янко, МиколА 1998. Топонімічний словник України. Словник-довідник. Знання, Київ.

LUCSIK 2014. = ЛучИК, ВАСИль 2014. Етимологічний словник топонімів України. Академія, Київ.

\section{Hivatkozott irodalom}

BAUKO JÁNOS 2020. Magyar tulajdonnevek a cseh és szlovák névszótárakban. In: FARKAS TAMÁS SLíz MARIANN szerk., Tulajdonnevek és szótárak. ELTE Magyar Nyelvtudományi és Finnugor Intézet - Magyar Nyelvtudományi Társaság, Budapest. 199-207. https://doi.org/10.26546/ $\underline{4892373.12}$

BENÖ ATTILA 2020. Magyar tulajdonnevek a román névszótárakban. In: FARKAS TAMÁs - SLíz MARIANN szerk., Tulajdonnevek és szótárak. ELTE Magyar Nyelvtudományi és Finnugor Intézet - Magyar Nyelvtudományi Társaság, Budapest. 187-197. https://doi.org/10.26546/ $\underline{4892373.11}$

Drăganu, Nicolae 1933. Romanii in Veacurile IX-IV. Pe baza toponimiei şi a onomasticei. Academia Română, Bucureşti.

FNESz. = KISS LAJOS, Földrajzi nevek etimológiai szótára 1-2. 4., bővített és javított kiadás. Akadémiai Kiadó, Budapest, 1988.

SEBestyén Zsolt 2009. Pavlo Csucska: Прізвища закарпатських українців. Історикоетимологічний словник. [Recenzió.] Névtani Értesitő 31: 267-271.

SEBESTYÉn ZsOLT 2010. Bereg megye helységneveinek etimológiai szótára. Bessenyei Könyvkiadó, Nyíregyháza. 
SEBESTYÉN ZSOLT 2012. Máramaros megye helységneveinek etimológiai szótára. Bessenyei Könyvkiadó, Nyíregyháza.

SEBESTYÉN ZSOLT 2016. В. В. Лучик: Етимологічний словник топонімів України. [Recenzió.] Névtani Értesitö 38: 255-257.

SEBESTYÉN ZSOLT - ÚR LAJOS 2014. Ung megye helységneveinek etimológiai szótára. K. n., Ungvár. SHU. = Словник гідронимів України . Szerk. НЕПОКУПНИЙ, АНАТОЛИЙ ПАВЛОВИч - СТРИЖАК, ОЛЕКСІй СИЛЬВЕСТРОВИЧ - ЦІЛУЙКО, КИРИЛО КУзЬМОвИч. Наукова Думка, Київ, 1978. StANISLAV, JÁN 1948. Slovenskýjuh v stredoveku 1-2. Matica slovenská, Turčiansky Sv. Martin. VERBICS 2013. = ВЕРБИЧ, СВятОсЛАВ 2013. Українська ономастика. Бібліографічний покажчик. Національна академія наук України Інститут української мови, Київ.

SEBESTYÉN ZSOLT

ORCID: https://orcid.org/0000-0002-1817-424X

Nyíregyházi Egyetem

Nyelv- és Irodalomtudományi Intézet

\section{ZSOLt SEBESTYÉN, Hungarian proper names in Ukrainian name dictionaries}

Ukrainian onomastics has undergone significant development in recent decades. The number of dictionaries and monographs published reflects the productive nature of this research. However, academic interest only turned towards the Transcarpathian name stock in the second half of the $20^{\text {th }}$ century or after the turn of the millennium. Organized, extensive name collections have not taken place in the county to the present day; attention is generally limited to selected sub-issues. The study presents Ukrainian etymological dictionaries of names that contain Hungarian-related data. The historical and ethnic characteristics of the region must be taken into consideration when studying the Transcarpathian name stock. Unfortunately, the Hungarian name stock receives little attention, which is partly due to linguistic reasons but primarily a political decision. The authors of geographical name dictionaries often omit historical Hungarian toponyms from their works, only discussing the Ukrainian names that have been used officially since 1946 . Personal name dictionaries contain an increased number of Hungarian data, but the general tendency to emphasize the Slavic traditions of the region over the linguistic facts of a Hungarian past are apparent in these as well. 